\title{
Tinea nigra on the fingers
}

Berna Solak, ${ }^{1}$ Zeynep Unus ${ }^{2}$

${ }^{1}$ Department of Dermatology, School of Medicine, Sakarya University, Sakarya, Turkey ${ }^{2} S$ chool of Medicine, Sakarya University, Sakarya, Turkey

\section{Correspondence to}

Dr Berna Solak,

bernasolakmd@gmail.com

Accepted 17 November 2015

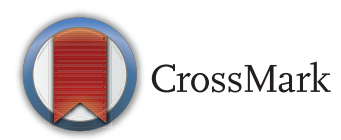

To cite: Solak B, Unus $Z$. BMJ Case Rep Published online: [please include Day Month Year] doi:10.1136/ bcr-2015-211124

\section{DESCRIPTION}

A 57-year-old man presented to the emergency room, with sudden onset of brown spots on his fingers. He denied any trauma or tattoos in these areas, had not travelled to tropical or subtropical regions, and did not have a history of any systemic disease and did not use drugs. He was a farmer and had close contact with water and plants. On dermatological examination, there were light brown macules on the second, third and forth fingers of his left hand (figure 1A, B). Basic laboratory tests were normal. Arterial duplex ultrasound of this extremity was normal, ruling out stenosis. We performed 15\% potassium hydroxide $(\mathrm{KOH})$ examination with scraps from the lesion, which revealed brownish septate hyphae with budding pigmented yeast-like cells. On dermoscopic examination, light brown reticulate patches formed by superficial fine, wispy strands that did not follow the furrows and ridges were seen (figure 2). We diagnosed the patient as having tinea nigra, for which isoconazole nitrate cream (Travogen) was started. After 2 weeks, the lesions almost completely disappeared (figure 1C, D).

Tinea nigra is a rare superficial mycosis, seen particularly in tropical regions, and caused by Hortaea werneckii. Hyperhydrosis and living in coastal regions or hypersaline environments are predisposing factors. ${ }^{1}$ The condition is characterised by pigmented, macular patches localised on the palms or soles, which potentially mimic pigmentary lesions such as melanoma, especially when presenting as a solitary lesion. ${ }^{2}$ Once suspected, it can easily be diagnosed with a simple $\mathrm{KOH}$ and dermoscopic

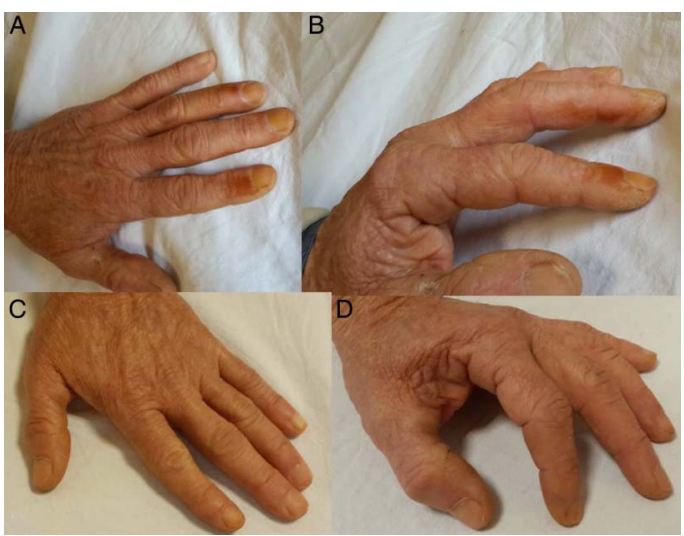

Figure 1 ( $A$ and $B$ ) Light brown macules on the second, third and fourth fingers of the left hand. (C and D) The appearance of the second, third and fourth fingers 2 weeks after treatment.

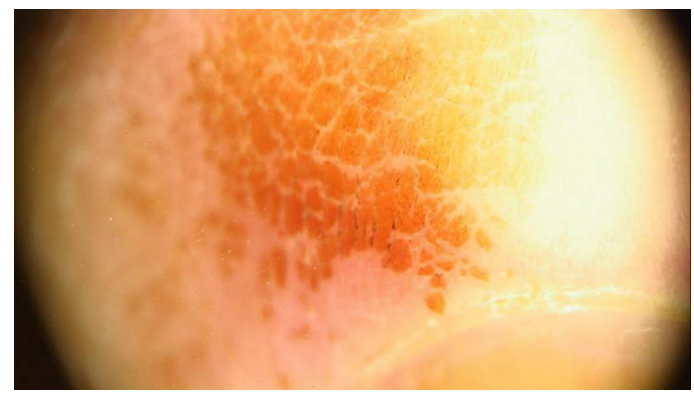

Figure 2 Dermoscopically, light brown reticulate patches formed of superficial fine, wispy strands that do not follow the furrows and ridges (original magnification $\times 10)$.

examination or culture. Thus, the patient avoids unnecessary interventions such as biopsy.

\section{Learning points}

- Tinea nigra usually presents with asymptomatic, pigmented, macular patches on the palms or soles, mimicking pigmentary lesions such as melanoma, especially when presenting as a solitary lesion.

- Tinea nigra may also be seen in non-tropical regions and on unusual body parts such as fingers, as in our case, rather than being limited to the palms and soles.

- It is easy to diagnose and treat tinea nigra when it is kept in the differential diagnosis. Thus, the patient avoids unnecessary interventions such as biopsy.

Contributors BS performed the $\mathrm{KOH}$ examination and dermoscopic examination, and wrote the manuscript. ZU captured the images and performed the literature review. All the authors have seen and approved the manuscript.

Competing interests None declared.

Patient consent Obtained.

Provenance and peer review Not commissioned; externally peer reviewed.

\section{REFERENCES}

1 Bonifaz A, Badali $H$, de Hoog GS, et al. Tinea nigra by Hortaea werneckii, a report of 22 cases from Mexico. Stud Mycol 2008;61:77-82.

2 Piliouras $\mathrm{P}$, Allison S, Rosendahl C, et al. Dermoscopy improves diagnosis of tinea nigra: a study of 50 cases. Australas J Dermatol 2011;52:191-4. 
Copyright 2015 BMJ Publishing Group. All rights reserved. For permission to reuse any of this content visit http://group.bmj.com/group/rights-licensing/permissions.

BMJ Case Report Fellows may re-use this article for personal use and teaching without any further permission.

Become a Fellow of BMJ Case Reports today and you can:

- Submit as many cases as you like

- Enjoy fast sympathetic peer review and rapid publication of accepted articles

- Access all the published articles

- Re-use any of the published material for personal use and teaching without further permission

For information on Institutional Fellowships contact consortiasales@bmjgroup.com

Visit casereports.bmj.com for more articles like this and to become a Fellow 